\title{
Preliminary Account of a new Australian Peripatus.
} By Arthur Dendy, M.Sc., F.L.S.*

A few months ago I had the pleasure of reading before the Field Naturalists' Club a short account of a trip to Walhalla $\uparrow$, in which I described some of the Land-Planarians met with. As a result of this paper one of our members, Mr. H. R. Hogg, began to collect Planarians for me at Macedon. I requested him to look out also for Peripatus, and, with a view to so doing, he carefully examined some of my specimens of P. Leuckartii. Mr. Hogg has not been long in meeting with success in his researches into the cryptozoic fauna of Macedon, and a short time ago he kindly brought me a number of beautiful Planarians, all alive, and five specimens of Peripatus, two alive and three in spirits.

The Planarians I hope to describe at a future date; the Peripatus I propose to deal with in the present communication. Although all small, the specimens proved of the greatest interest, for they undoubtedly belong to a new species. The only Australian species of Peripatus hitherto described is P. Leuckartii, Sænger, which ranges through Queensland, New South Wales, and Victoria, and for details as to which I must refer the reader to my paper in the 'Proceedings of the Royal Society of Victoria' + . The only other Australasian species hitherto known is $P$. novcezealandice, Hutton, from New Zealand. Mr. Hogg's specimens differ in important particulars from both these species. The most important difference is in the number of pairs of legs, $P$. Leuckartii and $P$. novee-zealandice having each constantly 15 pairs, while the new species has only 14 . The new species differs from $P$. Leuckartii-to which it might be expected to be most nearly related-also in the structure of the jaws and in the pattern of the skin. The distinctness of the new species may be expressed by the statement that it differs more from either of the two previously known Australasian species than these do from ono another.

On the present occasion I shall describe only the external characters, but I hope in due course to be able to give a complete anatomical account of both the Australian species.

\section{Peripatus insignis $\S, \mathrm{sp}$. nov.}

Colour and Markings.-(a) Dorsal Surface.-The general appearance to the naked eye is dark, sometimes almost black, speckled with pale orange or yellow. Microscopical examination by reflected light shows that the skin is, as usual in the genus,

* Reprinted from the 'Victorian Naturalist,' April 1890.

† "Zoological Notes on a Trip to Walhalla," 'Victorian Naturalist,' December 1889.

$\ddagger$ "Observations on the Australian Species of Peripatus," part 1, Proceedings Royal Society of Victoria, July 1889.

\$ Insignis, distinguished by a mark.

Ann. \& Mag. N. Hist. Ser. 6. Vol. vi. 
divided into a very great number of narrow transverse ridges by very fine grooves of a pale yellow colour. Down the mid-dorsal line runs a narrow dark stripe with a very fine white, or almost white, line running down the middle of it as in P. Leuckartii.

The general ground-colour is dark indigo-blue, often almost black, and this is checkered by more or less regularly arranged patches of pale dull orange or yellow. The typical arrangement of these patches appears to be as follows:- There is a squarish patch just over the base of each leg, more distinct than any of the others. Between the legs of each pair, in the mid-dorsal line, is a similar patch, interrupted by the median longitudinal stripe already mentioned, and separated from the patch over the leg on either side by a space of about the same width as itself. Thus there is a transverse row of three patches between the legs of each pair, and with these rows alternate other rows of only two patches each, in such a manner that a kind of chessboard pattern is produced. Besides these patches there are on each side of the middorsal line several longitudinal rows (the typical number appears to be four on each side) of more or less regularly arranged dull orange or yellow papillæ. Sometimes the chessboard pattern is almost obliterated, leaving the longitudinal rows of papillæ scattered over a nearly uniform dark background. The dorsal surface of the legs is dark indigo-blue, with two or three orange or yellow papillæ.

(b) Ventral Surface.-The ground-colour is pale yellowish. Over this are scattered a number of papillæ, mostly of an indigoblue colour, but some dull orange; the papillæ are arranged in transverse rows, one row on each ridge of skin. The blue papillæ are most numerous along an imaginary line joining the bases of the legs of each side. In the mid-ventral line, between the legs of each pair except the last, is an unusually pale area of skin, devoid of papillæ, and sometimes presenting clear indications of a longitudinal slit-like aperture in its centre. I have described similar pale areas in P. Leuckartii, and cannot help thinking that they must have some important morphological significance. I hope to find out later on, when working out the anatomy, what this signicance may be.

(c) The Antennce.-These are of a dark indigo-blue colour.

I have attempted above to describe the characteristic pattern of the skin as deduced from five specimens, but it must be remembered that considerable individual variations are sure to occur, though probably, as in P. Leuckartii, all the variations will be found to be readily derivable from a typical pattern. This typical pattern is quite different in the two Australian species, as will be seen on comparing my deseriptions of $P$. Leuckartii (loc. cit.).

Size.-The five specimens at present to hand are all very small, the largest being only about eleven millimetres in length (excluding the antennæ), and one millimetre in greatest breadth, after preservation in spirits.

Legs.-These are fourteen in number on each side of the body. They have three spinous pads on the ventral surface, as described 
by Sedgwick* for the other Australian species. The feet closely agree with those of $P$. novce-zealandice, as figured by Sedgwick (loc. cit.), being provided with a dorso-median papilla above the claws and a lateral one on each side.

Jaws.-The outer blade of the jaw is simple, as in $P$. novcezealandice, and not provided with an accessory tooth as in $P$. Leuckartii.

Genital Aperture.-The genital aperture is situated between the legs of the last pair. In some specimens it is a very prominent white papilla; these are probably females. The other specimens, in which it is less prominent, may be young females or males, but I have found no white papilla on the base of the last leg, such as exists in the males of $P$. Leuckartii.

Habitat.-Macedon, Victoria. In and upon rotten wood.

\section{On the Compound Eyes of Arthropods.}

'Studies from the Biological Laboratory of Johns Hopkins University,' vol. iv. no. 6, contains a paper "On the Morphology of the Compound Eyes of Arthropods," by Mr. Sho Watase, which is of interest owing to its bearing on the origin of the compound eyes of insects.

The principal subject of the paper is the eye of Limulus; but types of the three great groups of Arthropods-Insecta, Crustacea, and Arachnids - were studied, and the results are included in the generalizations at the close of the paper.

The primitive type of the ommatidium, or visual unit, is traced into a simple open ectodermic pit, from which he believes the compound eyes of Arthropods to have developed by a vegetative repetition of similar structures, not unlike what is supposed to have taken place in the formation of certain compound organs in other animals, such as the kidney in Vertebrates or the respiratory organs in Lamellibranchs.

Taking the number of facets as given by Lubbock, the compound eye of the house-fly (Musca) would represent about 4000 invaginations of the skin, and of the dragon-fly (Eschna) about 20,000, while an ocellus would represent a single pit.

In an appendix the compound eye of the starfish is briefly considered, and is found to be morphologically strikingly similar to that of an Arthropod. Six lithographic plates accompany the paper and admirably illustrate the author's studies.-Insect Life, vol. ii. no. 10, April 1890, p. 293.

* "Monograph of the Species and Distribution of the Genus Peripatus (Guilding)," Quarterly Journal of Microscopical Science, April 1888. 


\section{$2 \mathrm{BHL}$ Biodiversity Heritage Library}

Dendy, Arthur. 1890. "Preliminary account of a new Australian Peripatus." The Annals and magazine of natural history; zoology, botany, and geology 6, 121-123. https://doi.org/10.1080/00222939008694007.

View This Item Online: https://www.biodiversitylibrary.org/item/88261

DOI: https://doi.org/10.1080/00222939008694007

Permalink: https://www.biodiversitylibrary.org/partpdf/65077

\section{Holding Institution}

Smithsonian Libraries

\section{Sponsored by}

Smithsonian

\section{Copyright \& Reuse}

Copyright Status: Public domain. The BHL considers that this work is no longer under copyright protection.

This document was created from content at the Biodiversity Heritage Library, the world's largest open access digital library for biodiversity literature and archives. Visit BHL at https://www.biodiversitylibrary.org. 